\title{
PIEMINOT DR. MED. VILI A. NĀGELI
}

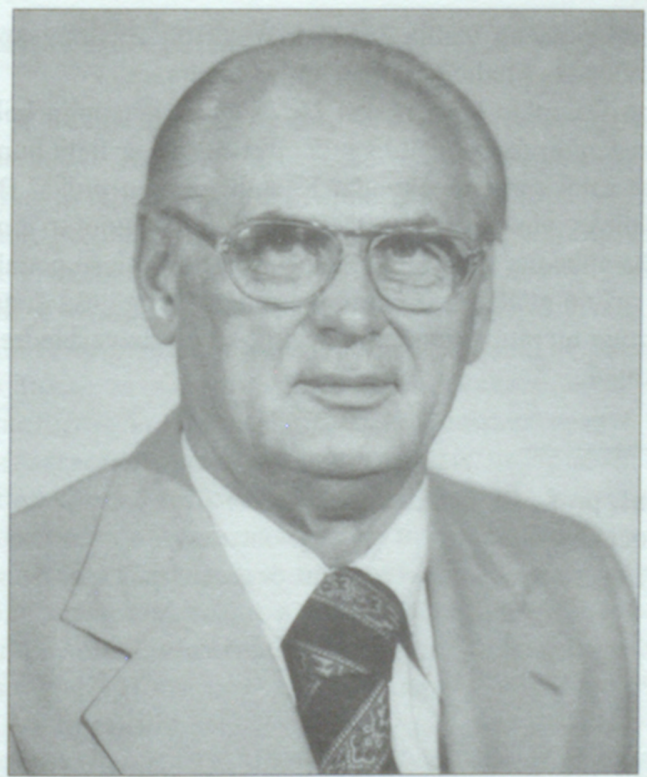

Dr. med. Vilis A. Nāgelis

Nodzīvojis raženu mūžu, 2004. gada 8. martā 92 gadu vecumā aizgāja mūžǐbā izcils un rūpīgs ārsts, kas daudz palīdzējis latviešu izce|otājiem trimdas sākuma gados un vēlāk. Vinš̌ bija viens no pēdējiem brīvās Latvijas Universitātes Medicīnas fakultātes absolventiem 1939. gadā.

Tūlīt pēc Medicīnas fakultātes beigšanas $D r$. Nāgelis uzsāka savas ārsta gaitas Alūksnē kā rajona ārsts. Pēc tam - no 1941. gada līdz izce|ošanai no Latvijas 1944. gadā - strādāja Rīgā par profesora Paula Stradiṇa vecāko asistentu.

No 1944. līdz 1949. gadam Dr. Nāgelis dzīvoja un strādāja Vācijā. Tā kā Latvijas Universitātes Medicīnas fakultātes ārsta diplomu atzina arī Vācijas ietādes, Dr. Nāgelis varêja strādāt par ārstu Sudetijā, vietêjā slimnīcā, bet vêlāk Apvienoto 
Nāciju Palīdzības un atjaunošanas administrācijas (UNRRA, United Nations Relief and Rehabilitation Administration) slimnīcā, kā arī bija Starptautiskās bēglu organizācijas (IRA, International Refugee Organization) tuberkulozes slimnīcas direktors Ambergā.

Arī Amerikas Savienotajās Valstīs atzina LU diplomus medicīnā, tomēr katrā štatā bija jānokārto eksāmeni, lai iegūtu prakses tiesības. Šos eksāmenus Dr. Nāgelis nokârtoja tūlīt pēc iecelošanas 1949. gadā Ohaio štatā. Līdz pensionēšanās 1989. gadā un pārcelšanās uz Floridu viņš 40 gadu strādāja par ârstu vairākās Klīvlendas slimnīcās (Marymount, Womens). Pēdējā laikā bija Sieviešu slimnīcas šefārsts.

Dr. Nāgelis nodibināja un vadīja Latvijas Ārstu un zobārstu apvienības Ohaio nodalu, bija Klīvlendas Medicīnas akadēmijas biedrs.

Vienlaikus ar profesionālo ārsta praksi Dr. Nāgelis netaupijja laiku un līdzek|us latviešu sabiedriskajam darbam. Viņš bija apveltīts arī ar lielu humora izjūtu, bija gaidīts viesis ar savu šarmanto kundzi Kseniju draugu pulkā. Būdams latviešu draudzes priekšnieks, viņš spēja noturēt draudzi, neiek|aujot to amerikānu sinodē. Dr. Vilis Nāgelis apbedīts Klīvlendā, Sansetas kapu latviešu noda|ā. Bija liels pavadītāju pulks, arī no attālām pilsētām. No mūžǐibā aizgājušã ārsta atvadījās viṇa korporācijas Latvia un citu koporāciju locekli, kā arī dzīvesbiedre, bērni ar ġimenēm, radi un draugi.

Jãnis V. Kḷavin̄š, prof., Dr. med.

LZA ãrzemju loceklis,

Nujorka 